\title{
Implementasi Total Quality Management dan Innovation Capability dalam Meningkatkan Quality Performance
}

\author{
Devista Ayu Amalia ${ }^{1)}$, Dessy Isfianadewi ${ }^{2)^{*}}$ \\ ${ }^{1}$ Fakultas Bisnis dan Ekonomika, Universitas Islam Indonesia \\ email: devistaamalia13@gmail.com \\ ${ }^{2}$ Fakultas Bisnis dan Ekonomika, Universitas Islam Indonesia \\ email: dessy.isfianadewi@uii.ac.id
}

*correspondentauthor

\begin{abstract}
Total Quality Management is not the only tool to be able to advance a company to be better. Innovation is a way that can also be used as a tool to develop a company to be more developed and more innovative to improve the quality of company performance. This study aims to determine the effect of Total Quality Management and Innovation Capability on Performance Quality on pottery craftsmen in Kasongan Bantul, Yogyakarta. More competitors are entering the craft world, so the craftsmen are required to have a strategy to keep maintaining Kasongan Pottery. This study uses a quantitative approach. The research data was collected from questionnaires distributed to 135 craftsmen in Kasongan Pottery Crafts. The variables of this study were measured using statement items/questions with a 1-5 Likert Scale, starting from 1 = strongly disagree to 5 = strongly agree. The data analysis method in this research is the Structural Equation Model (SEM) using Partial Least Square (PLS) to test the hypothesis with SmartPLS 3.0 software. The results of this study indicate that Total Quality Management has a positive and significant influence on Innovation Capability. Total Quality Management and Innovation Capability has a positive and significant impact on Quality Performance
\end{abstract}

Keywords: Total Quality Management, Innovation Capability, Quality Performance

\begin{abstract}
Abstrak
Total Quality Manajemen bukanlah merupakan satu satunya alat untuk dapat memajukan suatu perusahaan agar lebih baik. Inovasi merupakan cara yang juga dapat dijadikan alat untuk memajukan suatu perusahaan agar lebih berkembang dan lebih inovatif untuk meningkatkan kualitas kinerja perusahaan. Penelitian ini bertujuan untuk mengetahui pengaruh Total Quality Management dan Innovation Capability terhadap Kualitas Kinerja pada pengrajin gerabah di Kasongan Bantul, Yogyakarta. Semakin banyaknya pesaing yang masuk ke dunia kerajinan, sehingga para pengrajin dituntut harus mempunyai strategi untuk tetap mempertahankan kerajinan Gerabah Kasongan. Penelitian ini menggunakan pendekatan kuantitatif. Data penelitian ini dikumpulkan dari kuestioner yang disebar kepada 135 pengrajin yang ada di Kerajinan Gerabah Kasongan. Variabel penelitian ini diukur dengan menggunakan item pernyataan/pertanyaan dengan Skala Likert 1-5, dimulai 1=sangat tidak setuju sampai 5=sangat setuju. Metode analisis data dalam penelitian ini adalah Structural Equation Model (SEM) dengan menggunakan Partial least square (PLS) untuk menguji hipotesis dalam penelitian ini dengan software SmartPLS 3.0. Hasil dari penelitian ini menunjukkan bahwa Total Quality Management memiliki pengaruh yang positif dan signifikan terhadap Innovation Capability. Total Quality Management dan Innovation Capability memiliki pengaruh yang positif dan signifikan terhadap Quality Performance
\end{abstract}

Kata Kunci: Total Quality Management, Innovation Capability, Quality Performance 


\section{A. PENDAHULUAN}

Daerah Istimewa Yogyakarta bukan hanya terkenal sebagai kota pelajar saja, namun juga terkenal sebagai kota yang memiliki pengrajin gerabah yang berpusat di Yogyakarta bagian selatan. Pengrajin Gerabah Kasongan harus mampu mengikuti perubahan zaman, namun tetap harus menjadikan tanah liat sebagai bahan utamanya. Pengrajin gerabah Kasongan dituntut untuk memproduksi barang barang dengan mutu terbaik, dengan menggunakan tanah liat atau bahan baku pilihan, peralatan, dan pembuatan gerabah yang sesuai dengan prosedurnya, sehingga konsumen merasa puas dan dapat menarik daya tarik masyarakat lainnya.

Salah satu strategi yang digunakan untuk dapat bertahan dalam persaingan saat ini adalah dengan menerapkan strategi Total Quality Management (TQM). TQM yang dimaksud merupakan pendekatan yang tujuannya untuk memaksimalkan daya saing melalui peningkatan kualitas produk, sumber daya manusia, layanan, proses, dan lingkungan yang berkelanjutan (Jumenez \& Martinez, 2009). TQM juga sebagai teknik perbaikan strategis yang digunakan untuk meningkatkan kualitas produk dan kinerja karyawan (Vanichchinchai, 2009; Psomas, 2016).

Total Quality Manajemen bukanlah merupakan satu satunya alat untuk dapat memajukan suatu perusahaan agar lebih baik,inovasi merupakan cara yang juga dapat dijadikan alat untuk memajukan suatu perusahaan agar lebih berkembang dan lebih inovatif. Inovasi adalah kemampuan organisasi yang penting, karena keberhasilan produk baru adalah mesin pertumbuhan yang berdampak pada peningkatan penjualan, keuntungan, dan kekuatan persaingan bagi banyak organisasi (Battor, 2010; Sivadas, 2000).

Demi kemajuan suatu perusahaan, penerapan lain yang biasanya digunakan untuk memajukan perusahaan adalah dengan memperhatikan kualitas kinerja. Kualitas kinerja adalah salah satu dari berbagai instrumen strategi kompetitif dalam bisnis. Dengan demikian, perusahaan telah memperhatikan bahwa kualitas kinerja adalah faktor utama yang penting untuk mengembangkan produk dan layanan untuk mendorong pencapaian yang berkelanjutan (Boateng-Okrah, 2012). Dalam mencapai kualitas kinerja yang bagus perusahaan harus mengimplementasikan Innovation Capability ( Raja, 2014; James Agarwal, 2014). Sehingga penting untuk dilakukan penelitian untuk mengetahui implementasi Total Quality Management dan Innovation Capability dalam meningkatkan Kualitas Kinerja. 


\section{B. TINJAUAN PUSTAKA}

\section{1) Total Quality Management dan Innovation Capability}

Total Quality Management (TQM) adalah pendekatan yang tujuannya untuk memaksimalkan daya saing melalui peningkatan kualitas produk, sumber daya manusia, layanan, proses, dan lingkungan yang berkelanjutan (Jumenez \& Martinez, 2009). Selain itu Oakland, (2014) mendefinisikan TQM adalah pendekatan untuk meningkatkan daya saing, efektivitas dan fleksibilitas dari seluruh organisasi. Bahwa pada dasarnya $T Q M$ ini adalah cara merencanakan, mengatur, dan memahami setiap kegiatan, dan bergantung pada masing-masing individu di setiap level. Agar suatu organisasi benar-benar efektif, setiap bagiannya harus bekerja bersama-sama dengan baik untuk mencapai tujuan yang sama. Metode dan teknik yang digunakan dalam TQM dapat diterapkan di seluruh organisasi. TQM berguna dalam industri manufaktur, pelayanan publik, perawatan kesehatan, pendidikan dan perhotelan.

Studi yang dilakukan di Yunani mengidentifikasi kepemimpinan, perencanaan kualitas strategis, manajemen dan keterlibatan karyawan, manajemen pemasok, pelanggan, manajemen proses, peningkatan berkelanjutan, informasi dan analisis serta pengetahuan dan pendidikan sebagai serangkaian praktek TQM untuk membentuk hubungan struktural dengan kinerja organisasi pada perusahaan bersertifikat ISO 9001: 2000 (Fotopoulos, 2010)

Seperti halnya penelitian yang dilakukan pada perusahaan jasa membuktikan bahwa implementasi TQM ditemukan sebagian berkorelasi dengan kualitas kinerja perusahaan dan ditemukan bahwa budaya kualitas dianggap sebagai implementasi TQM yang dominan dalam kualitas kinerja. Implementasi lain seperti sistem mutu, pelatihan dan pendidikan, kerja tim, dan pembandingan menunjukkan hubungan positif dengan kualitas kinerja (Talib, Rahman,Qureshi, 2013)

Kemampuan inovasi (terdiri dari kemampuan inovasi produk dan kemampuan inovasi proses) diakui sebagai salah satu sumber daya internal paling penting yang dapat menghasilkan kinerja perusahaan yang unggul (Perna, 2015). Kemampuan perusahaan untuk berinovasi adalah faktor yang paling penting untuk keunggulan kompetitif dalam kondisi pasar yang sangat bergejolak. Kemampuan inovasi mengarahkan organisasi untuk mengembangkan inovasi secara terus menerus untuk merespon lingkungan pasar yang berubah (Slater, 2010) dan tertanam dengan semua strategi, sistem dan struktur 
yang mendukung inovasi dalam suatu organisasi (Gloet, 2016). Hasil dari penelitian tersebut sesuai dengan penelitian Yusr (2016), yang menemukan bahwa total quality management memiliki pengaruh hubungan yang positif dan secara signifikan terhadap innovation capability

H1: Total Quality Management memiliki pengaruh positif terhadap Innovation Capability

\section{2) Total Quality Management dan Quality Performance}

Total Quality Management (TQM) merupakan salah satu upaya yang dilakukan oleh suatu perusahaan untuk mendongkrak keunggulan perusahaan melalui pemenuhan kebutuhan pelanggan dan peningkatan kualitas melalui perbaikan secara berkala dan berkelanjutan (Zhang, 2000; Muttaqin \& Dharmayanti, 2015). Suatu studi mengidentifikasi kepemimpinan, perencanaan kualitas strategis, manajemen dan keterlibatan karyawan, manajemen pemasok, pelanggan, manajemen proses, peningkatan berkelanjutan, informasi dan analisis serta pengetahuan dan pendidikan sebagai serangkaian praktek TQM untuk membentuk hubungan struktural dengan kinerja organisasi di perusahaan Yunani bersertifikat ISO 9001: 2000 (Fotopoulos, 2010)

Kualitas adalah salah satu dari berbagai instrumen strategi kompetitif dalam bisnis. Dengan demikian, perusahaan telah memperhatikan bahwa kualitas adalah faktor utama yang penting untuk mengembangkan produk dan layanan untuk mendorong pencapaian kinerja yang berkelanjutan (Boateng-Okrah, 2012). Beberapa perusahaan telah merekomendasikan Total Quality Management untuk diterapkan didalam perusahaannya untuk mendongkrak keunggulan perusahaan melalui pemenuhan kebutuhan pelanggan dan peningkatan kualitas melalui perbaikan secara berkelanjutan (Muttaqin \& Dharmayanti, 2015)

Penelitian yang dilakukan oleh Zehir, Ertosun, Zehir, \& Müceldilli, (2012) mempunyai tujuan utama yaitu untuk menyelidiki apakah kegiatan TQM mempengaruhi kualitas dan /atau kinerja inovatif dan juga mendefinisikan komponen yang efektif pada jenis kinerja ini. 
H2: Total Quality Management berpengaruh positif terhadap Kualitas Kinerja

\section{3) Innovation Capability and Quality Performance}

Studi empiris terbaru pada pengembangan kemampuan inovasi,berfokus pada bagaimana perusahaan secara praktis mengembangkan kemampuan untuk berinovasi (Aggeri, 2009; Borjesson, 2013; Borjesson, 2011;Wallin, 2011;Samson, 2013). Inovasi merupakan suatu hal yang sangat penting, karena memiliki beberapa alasan, diantaranya (Keeh, 2007):

1. Harus melakukan inovasi teknologi baru. Perubahan teknologi yang sangat cepat sangat mempengaruhi produk, proses dan layanan, dan hal ini mendorong usaha entrepreneurial untuk bersaing.

2. Produk dan layanan semakin lama harus diganti dengan yang baru dalam waktu yang cepat, hal ini dikarenakan siklus hidup produk yang semakin pendek.

3. Konsumen saat ini lebih pintar dan menuntut dalam memenuhi pemenuhan kebutuhan. Konsumen mengharapkan kualitas, pembaruan, dan harga yang lebih baik. Oleh karena itu skill inovatif dibutuhkan untuk memuaskan kebutuhan konsumen sekaligus mempertahankan konsumen sebagai pelanggan.

4. Saat ini pasar dan teknologi berubah dengan sangat cepat, ide yang bagus dapat semakin mudah ditiru,

5. Inovasi bisa menghasilkan pertumbuhan yang lebih cepat, meningkatkan segmen pasar, dan menicptakan posisi korporat yang lebih baik.

Kualitas merupakan suatu istilah relatif yang sangat bergantung pada situasi. Produk dikatakan berkualitas apabila produk tersebut memiliki kecocokan penggunaan bagi produk itu sendiri (Zhang\& Hartley, 2018). Kualitas kinerja merupakan hasil kerja seorang karyawan yang sesuai dengan keinginan dan harapan konsumen untuk mencapai tujuan organisasi. Strategi yang digunakan perusahaan untuk membuat perusahaannya menjadi lebih unggul adalah dengan memberikan pelayanan yang memuaskan dan memiliki kualitas dan mutu yang tinggi, hal itu dilakukan untuk memenuhi kepentingan konsumen. Kualitas kinerja perusahaan sangat terkait dengan kemampuan organisasi dalam kemampuannya bersaing secara kompetitif di pasar 
global. (Muttaqin \& Dharmayanti, 2015). Hal ini sejalan dengan penelitian yang dilakukan oleh Zehir, Ertosun, Zehir, \& Müceldilli, (2012)yang menyelidiki apakah kegiatan TQM mempengaruhi kualitas dan /atau kinerja inovatif dan juga mendefinisikan komponen yang efektif pada jenis kinerja ini.

H3: Innovation Capability berpengaruh positif terhadap Quality Performance

\section{METODE PENELITIAN}

\section{1) Desain Penelitian}

Populasi yang digunakan dalam penelitian ini adalah Usaha Mikro Kecil dan Menengah (UMKM) di industri gerabah Kasongan, yang berada di kabupaten Bantul, provinsi D.I.Y. Kabupaten tersebut memiliki sekitar 537 pengrajin gerabah. Teknik penarikan sampel yang digunakan adalah Proportionate Stratified Random Sampling, diperoleh 135 sampel (Sekaran \& Bougie, 2013). Metode analisis data dalam penelitian ini adalah Structural Equation Model (SEM). Penelitian ini menggunakan Partial least square (PLS) untuk menguji hipotesis dengan software SmartPLS 3.0. Data yang digunakan adalah data primer, yang dikumpulkan dengan melakukan penyebaran kuesioner sebanyak 135 dan dibagikan kepada para pengrajin yang ada di Kerajinan Gerabah Kasongan Bantul, Yogyakarta

\section{2) Variabel dan Pengukuran}

Penelitian ini menggunakan 3 (tiga) variabel, yang 2 (dua) diantaranya menggunakan variable eksogen, yaitu Total Quality Management dan Innovation Capability, dan 1 (satu) variabel endogen, yaitu Kualitas Kinerja atau Quality Performance. Masing - masing variabel diukur dengan menggunakan indikator item pernyataan/pertanyaan dengan menggunakan skala Likert 1-5, dimulai 1=sangat tidak setuju sampai 5=sangat setuju.

1. Total Quality Management, dilihat dari 6 dimensi peningkatan kualitas produk, keterlibatan karyawan, team work, desain produk dan layanan, manajemen proses, serta perbaikan dan inovasi berkelanjutan. Dimensi - dimensi tersebut diukur menggunakan 14 item pernyataan/pertanyaan (Jumenez \& Martinez, 2009; Talib, Qureshi, \& Zillur, 2013) 
2. Innovation Capability, diukur melalui 3 item pernyataan/pertanyaan (Zhang \& Hartley, 2018; Perna, 2015).

3. Kualitas Kinerja, diukur melalui 3 item pernyataan/pertanyaan (Muttaqin \& Dharmayanti, 2015).

Daftar pernyataan/pertanyaan untuk setiap variabel dapat dilihat pada tabel betikut:

Tabel 1: Daftar Penyataan/Pertanyaan Setiap Variabel dan Dimensi

\begin{tabular}{|c|c|}
\hline No & Variabel dan Item Pernyataan/Pertanyaan \\
\hline & Total Quality Management \\
\hline & Perbaikan dan Inovasi Berkelanjutan \\
\hline 1 & Manajemen menekankan peningkatan kualitas yang berkesinambungan \\
\hline \multirow[t]{2}{*}{2} & Perusahaan percaya bahwa "perbaikan terus-menerus" menghasilkan keunggulan kompetitif \\
\hline & Fokus terhadap Pelanggan \\
\hline 3 & Produk dan layanan informasi dan perincian disediakan oleh perusahaan \\
\hline \multirow[t]{2}{*}{4} & Umpan balik pelanggan digunakan sebagai dasar peningkatan kualitas \\
\hline & Management Proses \\
\hline 5 & Proses dan prosedur disederhanakan dan dirincikan \\
\hline \multirow[t]{2}{*}{6} & $\begin{array}{l}\text { Penekanan pada pengukuran keluhan pelanggan dengan melibatkan dan mengambil umpan } \\
\text { balik dari pelanggan untuk peningkatan pengiriman layanan }\end{array}$ \\
\hline & Keterlibatan Karyaman \\
\hline 7 & Manajemen mendorong karyawan untuk berpartisipasi dalam mencapai tujuan organisasi \\
\hline 8 & Karyawan didorong untuk memberikan saran dan inovasi \\
\hline \multirow[t]{2}{*}{9} & Karyawan dievaluasi dan diberikan feedback \\
\hline & Team Work \\
\hline 10 & Karyawan saling mempercayai dan bekerja sebagai satu tim \\
\hline \multirow[t]{2}{*}{11} & $\begin{array}{l}\text { Anggota tim secara rutin terlibat dalam memecahkan masalah perusahaan melalui sesi curah } \\
\text { pendapat, sesi pengambilan keputusan, pertemuan kelompok, dll }\end{array}$ \\
\hline & Desain Produk dan Layanan \\
\hline 12 & $\begin{array}{l}\text { Perusahaan mengevaluasi dan meningkatkan desain dan proses desain untuk peningkatan } \\
\text { kualitas layanan }\end{array}$ \\
\hline 13 & $\begin{array}{l}\text { Produk dan layanan dirancang dan dikembangkan berdasarkan kebutuhan dan harapan } \\
\text { pelanggan }\end{array}$ \\
\hline \multirow[t]{2}{*}{14} & Produk baru dan desain layanan ditinjau sebelum diproduksi dan dipasarkan \\
\hline & Innovation Capability \\
\hline 15 & $\begin{array}{l}\begin{array}{l}\text { Perusahaan kami menggunakan pengetahuan dari berbagai sumber untuk kegiatan } \\
\text { pengembangan produk secara efisien dan cepat }\end{array} \\
\end{array}$ \\
\hline 16 & $\begin{array}{l}\text { Perusahaan kami mendukung dan mendorong pekerja untuk berpartisipasi dalam kegiatan } \\
\text { seperti pengembangan produk, peningkatan proses inovasi, dan generasi ide. }\end{array}$ \\
\hline \multirow[t]{2}{*}{17} & $\begin{array}{l}\text { Perusahaan kami terus-menerus mengevaluasi ide-ide baru yang datang dari pelanggan, } \\
\text { pemasok, dll dan memasukkannya ke dalam kegiatan pengembangan produk }\end{array}$ \\
\hline & Quality Performance \\
\hline 18 & Produk memiliki fitur/karakteristik yang berbeda bila dibandingkan dengan pesaing \\
\hline 19 & Perusahaan kami sering melakukan peningkatan kualitas \\
\hline 20 & Fungsi produk di atas rata-rata jika dibandingkan dengan pesaing \\
\hline
\end{tabular}




\section{HASIL DAN PEMBAHASAN}

\section{1) Karakteristik dan Profil Responden}

Karakteristik responden dalam penelitian ini dijelaskan dalam beberapa kriteria yaitu: jenis kelamin, usia, status, pendidikan dan penghasilan. Karakteristik responden dapat dijabarkan sebagai berikut:

Tabel 1: Karakteristik Responden

\begin{tabular}{|l|l|l|}
\hline Karakteristik Responden & Frekuensi & Persentase \\
\hline Jenis Kelamin & & \\
Laki-laki & 78 & $57.8 \%$ \\
Perempuan & 57 & $42.2 \%$ \\
\hline Usia & & \\
$19-30$ tahun & 66 & $48.9 \%$ \\
$31-40$ tahun & 40 & $29.6 \%$ \\
$41-50$ tahun & 29 & $21.5 \%$ \\
\hline Status & & \\
Lajang & 31 & $23.0 \%$ \\
Menikah & 104 & $77.0 \%$ \\
\hline Pendidikan & & \\
SD & 19 & $14.0 \%$ \\
SMP & 36 & $26.7 \%$ \\
SMA & 49 & $36.3 \%$ \\
Lainnya & 31 & $23.0 \%$ \\
\hline Penghasilan & & \\
$<1.000 .000$ & 86 & $65.7 \%$ \\
$1.000 .000-5.000 .000$ & 49 & $36.3 \%$ \\
$>5.000 .000$ & 0 & $100 \%$ \\
\hline TOTAL & 135 & \\
\hline
\end{tabular}

Sumber: Data Diolah

Berdasarkan tabel 1 dapat diketahui bahwa jumlah responden laki-laki lebih banyak jika dibandingkan dengan responden perempuan. Responden laki-laki sebanyak $78(57.8 \%)$ orang sedangkan responden perempuan $57(42.2 \%)$ orang. Sedangkan berdasarkan usia, rata-rata respondennya adalah berusia 19-30 tahun sebanyak 66 orang (48.9\%) , sisanya berumur 31-40 orang sebanyak 40 orang (29.6\%) dan 41-50 tahun sebanyak 29 orang $(21.5 \%)$. Sementara itu berdasarkan status dari para responden ratarata sudah menikah, sebanyak 104 responden (77.0\%), dan sisanya 31 responden $(23.0 \%)$ yang masih lajang. Pendidikan terakhir para responden rata-rata adalah lulusan SMP dan SMA, lulusan SMA sebanyak 49 orang (36.3\%), lulusan SMP sebanyak 36 orang (26.7\%), lulusan SD sebanyak 19 orang (14.0\%), dan lulusan sarjana ataupun tidak pernah sekolah sebanyak 19 orang $(23.0 \%)$. Dan yang terakhir adalah berdasarkan pendapatan. Pendapatan para responden kurang dari Rp 1.000.000,00 sebanyak 86 
orang (65.7\%) dan yang lebih dari Rp 1.000.000,00 kurang dari Rp 5.000.000,00 adalah sebanyak 49 orang $(36.3 \%)$.

\section{2) Uji Validitas dan Reliabilitas}

Tabel 2: Konstruk Reliabilitas dan Validitas

\begin{tabular}{|c|c|c|c|}
\hline Variabel & $\begin{array}{c}\text { Cronbach's } \\
\text { Alpha }\end{array}$ & $\begin{array}{c}\text { Composite } \\
\text { Reliability }\end{array}$ & Average Variance Extracted (AVE) \\
\hline TQM & 0.832 & 0.868 & 0.673 \\
\hline IC & 0.739 & 0.849 & 0.653 \\
\hline QP & 0.731 & 0.847 & 0.649 \\
\hline
\end{tabular}

Sumber: Data Diolah

Tabel 2 menjelaskan bahwa nilai dari semua variabel berdasarkan Cronbach's alpha maupun composite reliability nilainya $>0.70$, dan pengujian validitas menggunakan AVE > 0.50, jadi variabel-variabel yang diujikan valid dan reliabel, sehingga dapat dilanjutkan untuk menguji model struktural.

\section{3) Uji Hipotesis}

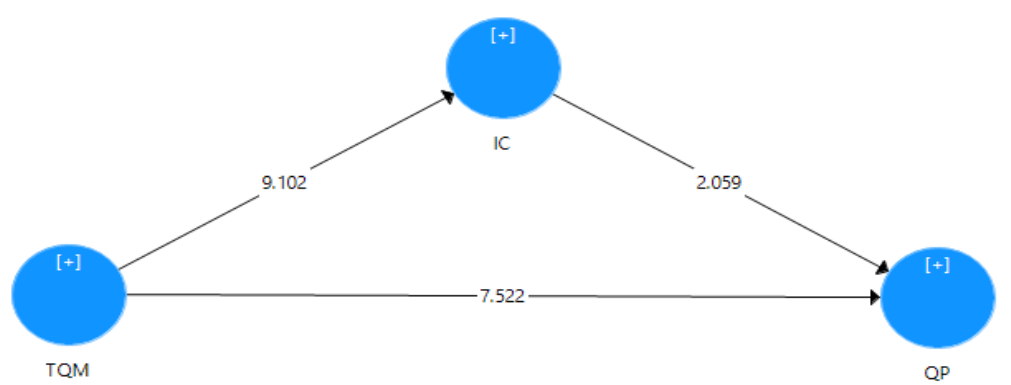

Gambar 1: Pengujian Model Struktural

Metode bootstrapping dilakukan untuk mengetahui pengaruh antar variabel. Dalam metode PLS, pengambilan keputusan diterima atau ditolaknya sebuah hipotesis didasarkan pada nilai signifikansi (p-value), dan nilai t-table. Kriteria dalam penerimaan atau penolakan hipotesis (Bootstrapping) adalah jika nilai signifikansi t-value $>1.96$ dan nilai p-value nya $<0.05$ pada taraf signifikansi 5\% $(\alpha=5 \%)$, maka Ho akan ditolak.

Berikut hipotesis- hipotesis yang diuji dalam penelitian ini:

1. Ho: Tidak terdapat pengaruh positif dari total quality management terhadap innovation capability

Ha: Terdapat pengaruh positif dari total quality management terhadap innovation capability 
2. Ho: Tidak terdapat pengaruh positif dari total quality management terhadap quality performance

Ha: Terdapat Pengaruh Positif dari total quality management terhadap quality performace

3. Ho: Tidak terdapat pengaruh positif dari innovation capability terhadap quality performance

Ha: Terdapat pengaruh positif dari innovation capability terhadap quality performance

Tabel 3: Path Coefficient

\begin{tabular}{|c|c|c|c|c|c|}
\hline Konstruk & $\begin{array}{c}\text { Original } \\
\text { Sample (O) }\end{array}$ & $\begin{array}{c}\text { Sample } \\
\text { Mean (M) }\end{array}$ & $\begin{array}{c}\text { Standard } \\
\text { Deviation } \\
(\text { STDEV) }\end{array}$ & $\begin{array}{c}\text { T Statistics } \\
(\mid \text { OSTDEV|) }\end{array}$ & P Values \\
\hline IC -> QP & 0.415 & 0.491 & 0.066 & 2.059 & 0.040 \\
\hline TQM -> QP & 0.557 & 0.577 & 0.074 & 7.522 & 0.000 \\
\hline TQM -> IC & 0.578 & 0.600 & 0.064 & 9.102 & 0.000 \\
\hline
\end{tabular}

Sumber: Data Diolah

Berdasarkan tabel 3 dapat dilihat bahwa konstruk total quality management mempunyai pengaruh positif yang signifikan $(\mathrm{O}=0.578)$ dengan konstruk innovation capability. Nilai t-statistic pada hubungan konstruk ini adalah $9.102>1.96$, dan nilai p-value $0.000<0.05$. Ho ditolak,sehingga hipotesis pertama yang menyatakan bahwa total quality management mempunyai pengaruh yang positif terhadap innovation capability terbukti. Hasil dari penelitian ini sesuai dengan penelitian terdahulu oleh Yusr (2016), yang menemukan bahwa total quality management memiliki pengaruh hubungan yang positif dan secara signifikan terhadap innovation capability

Konstruk Eksogen total quality management mempunyai pengaruh positif yang signifikan $(\mathrm{O}=0.557)$ terhadap konstruk Endogen quality performance. Hal ini berdasarkan pada nilai t-statisticpada hubungan konstruk ini adalah 7.522> 1.96, dan nilai p-value $0.000<0.05$. Ho ditolak, sehingga hipotesis kedua yang menyatakan bahwa total quality management mempunyai pengaruh yang positif terhadap quality performance terbukti. Hasil penelitian ini sesuai dengan penelitian Zehir, Ertosun, Zehir, Müceldilli (2012), yang menyatakan bahwa terdapat pengaruh positif total quality management terhadap quality performance. Hasil ini juga didukung oleh penelitian terdahulu yang dilakukan Talib, Rahman ,Qureshi (2013), yang mengungkapkan adanya pengaruh positif dan signifikan antara total quality management dengan quality performance. 
Konstruk Eksogen innovation capability mempunyai pengaruh positif yang signifikan $(\mathrm{O}=0.415)$ terhadap konstruk Endogen quality performance. Hal ini berdasarkan pada nilai t-statistic pada hubungan konstruk ini adalah 6.059>1.96, dan nilai p-value $0.040<0.05$. Ho ditolak, sehingga hipotesis ketiga yang menyatakan bahwa innovation capability mempunyai pengaruh yang positif terhadap quality performance terbukti. Hal ini juga sesuai dengan hasil penelitian yang dilakukan oleh Raja (2014), menyatakan bahwa ada pengaruh positif dan signifikan dari innovation capability terhadap quality performance. Begitu juga penelitian yang dilakukan oleh James Agarwal, (2014), mengungkapkan bahwa dari tiga jenis innovation capability yang diteliti, semuanya memiliki pengaruh yang positif dan signifikan terhadap quality performance.

Tabel 4: Rangkuman Hasil Uji Hipotesis

\begin{tabular}{|c|l|c|c|}
\hline No & \multicolumn{1}{|c|}{ Hipotesis } & T-statistik & Kesimpulan \\
\hline 1 & $\begin{array}{l}\text { Total quality management mempunyai } \\
\text { pengaruh yang positif terhadap } \\
\text { innovation capability }\end{array}$ & 9.102 & Ho ditolak \\
\hline 2 & $\begin{array}{l}\text { Total quality management mempunyai } \\
\text { pengaruh yang positif terhadap quality } \\
\text { performance }\end{array}$ & $\begin{array}{l}\text { Innovation capability mempunyai } \\
\text { pengaruh yang positif terhadap quality } \\
\text { performance }\end{array}$ & Ho ditolak \\
\hline
\end{tabular}

Sumber: Data Dioleh

\section{E. SIMPULAN}

Berdasarkan hasil analisis dan pembahasan tentang implementasi total quality management dan innovation capability dalam meningkatkan quality performance, maka dapat diberikan beberapa kesimpulan sebagai berikut:

1. Terdapat pengaruh positif yang signifikan antara total quality management terhadap innovation capability yang dibuktikan dengan nilai signifikansi dari nilai t-statistic pada hubungan ini adalah 9.102> 1,96 dan nilai p-value 0,000 $<0.05$.

2. Terdapat pengaruh positif yang signifikan antara total quality management terhadap quality performance yang dibuktikan dengan nilai signifikansi dari nilai t-statistic pada hubungan ini adalah $7.522>1,96$, dan nilai p-value 0,000 $<0.05$. 
3. Terdapat pengaruh positif yang signifikan antara innovation capability terhadap quality performance yang dibuktikan dengan nilai signifikansi dari nilai t-statistic pada hubungan ini adalah $6.059>1,96$, dan nilai p-value 0,040 $<0,05$.

\section{DAFTAR PUSTAKA}

Aggeri, F. E. (2009). Managing learning in the automotive industry \&ndash; the innovation race for electric vehicles. International Journal of Automotive Technology and Management, 1-20.

Battor, M. \&. (2010). The impact of customer relationship management capability on innovation and performance. Journal of Marketing Management, 26(9e10), $842 \mathrm{e} 857$.

Boateng-Okrah, E. (2012). TQM implementation: a case of a mining company in Ghana. Benchmarking: An International Journal, 19(6), 743-759.

Borjesson, S. E. (2011). Develop ing innovation capabilities: a longitudinal study of a project at Volvo Cars. Creativity and Innovation Management, 20, 171-184.

Borjesson, S. E. (2013). The Challenges of innovation capability building: learning from longitudinal studies of innovation efforts at Renault and Volvo Cars. Fourth Coming Journal of Engineering Technology and Management, 31(1), $120-140$.

Fotopoulos, C. (2010). The structural relationships between total quality management factors and organizational performance. The TQM Journal, 22(5), 539-52.

Gloet, M. (2016). Knowledge management and systematic innovation capability. International Journal of Knowledge Management (IJKM), 12(2), 54-72.

James Agarwal, N. (2014). Quality performance of SMEs in a developing economy: direct and indirect effects of service innovation and entrepreneurial orientation. Journal of Business \& Industrial Marketing, 29(6), 454 - 468.

Jumenez, D. \& Martinez, C. (2009). The performance effect of HRM and TQM: a study in Spanish Organization. International Journal of Operations \& Production Management, 29(12), 266-289.

Keeh, H. T. (2007). The Effects of Entrepreneurial Orientation and Marketing Information on the Performance of SMEs. Journal of Business Venturing, 22, 592-611.

Muttaqin \& Dharmayanti, G. (2015). Pengaruh Implementasi Total Quality Management Terhadap Kinerja Keuangan Dengan Kualitas Kinerja Sebagai Variabel Intervening. Jurnal Akuntansi, XIX(1), 68-78. 
Oakland, j. (2014). Total quality management and operational excellence. Antunes, york Routledge.

Perna, A. B. (2015). Is the value created necessarily associated with money? On the connections between an innovation process and its monetary dimension: The case of Solibro's thin-film solar cells. Industrial Marketing Management, 46(0), $108-121$.

Psomas, L. J. (2016.). The impact of total quality management on service company performance: evidence from Spain. Int. J. Qual. Reliab. Manag., 33(3), 380398.

Raja, M. (2014). Relationship between Innovation, Quality Practices, and Firm Performance: A Study of Service Sector Firms in Pakistan. Journal of Management Research, 6(4), 124-140.

Sekaran,U.,\&Bougie,R.(2013).ResearchMethodsforBusiness:ASkillBuilding Approach. West Sussex: John Wiley \& SonsLtd.

Samson, D. \&. (2013). Innovation capability in Australian manufacturing organizations: an exploratory study. International Journal of Production Research, 1-19.

Sivadas, E. \&. (2000). An Examination of organizational factors influencing new product success in internal and alliance-based processes. Journal of Marketing, 64(1), 31-49.

Slater, S. F. (2010). Factors influencing the relative importance of marketing strategy creativity and marketing strategy implementation effectiveness. Industrial Marketing Management, 39(4), 551-559.

Talib, Rahman, Qureshi, F. (2013). An empirical investigation of. International Journal of Quality \& Reliability Management, 30(3), 280-318.

Vanichchinchai, A. I. (2009). Total quality management and supply chain management: similarities and differences. TQM J, 21 (3), 249-260.

Wallin, J. L. (2011). Measuring Innovation Capability-Assessing Collaborative Performance in Product-Service System Innovation. Functional Thinking for Value Creation. Springer, 207-212.

Yusr, M. M. (2016). Innovation capability and its role in enhancing the relationship between TQM practices and innovation performance. Journal of Open Innovation: Technology, Market, and Complexity, 2(6).

Zehir, Ertosun, Zehir, Müceldilli, C. (2012). Total Quality Management Practices' Effects on Quality Performance and Innovative Performance. Procedia - Social and Behavioral Sciences, 41, $273-280$.

Zhang \& Hartley, M. (2018). Guanxi, IT systems, and innovation capability: The moderating role of proactiveness. Journal of Business Research, 90, 75-86. 
Zhang, Z. (2000). Implementation of Total Quality Management An Empirical Study of Chinese Manufacturing Firms. Rijksuniversiteit Groningen, 1-206. 